\title{
Stepwise temperature regulation and its effect on growth, feeding and muscle growth patterns of juvenile Atlantic halibut (Hippoglossus hippoglossus L.)
}

\author{
Sondre V. Larsen • Albert K. Imsland • Petter Lohne • \\ Karin Pittman • Atle Foss
}

Received: 22 June 2010/Accepted: 29 November 2010/Published online: 30 December 2010

(C) The Author(s) 2010. This article is published with open access at Springerlink.com

\begin{abstract}
To investigate the possible direct effect of a stepwise reduction in temperature with increasing size on growth, feeding parameters and muscle growth patterns of juvenile Atlantic halibut (Hippoglossus hippoglossus L.), 804 juvenile halibut (mean initial weight individuals: $14.2 \mathrm{~g} \pm 0.2 \mathrm{SEM}$ ) were reared at constant 9,12 and $15^{\circ} \mathrm{C}$ or shifted (T-step, i.e. $15-12^{\circ} \mathrm{C}$ after 36 days) for 99 days. Despite indications of lower optimal temperature for growth with increasing size, equal end weights were obtained between the constant $12^{\circ} \mathrm{C}$, constant $15^{\circ} \mathrm{C}$ and T-step groups. Best overall growth was observed for the group kept at constant $12^{\circ} \mathrm{C}$. The limited effect of the T-step group may relate to the size at movement (too big), the temperatures investigated (close to optimum) and the time and size interval investigated (too narrow). Differences in growth were reflected more by alterations in feed intake $\left(C_{\mathrm{T}}\right.$ and $F \%$ ) than by differences in feed conversion efficiencies (FCE). Differences were found with respect to the density of muscle cells, whereas no differences were found between the average muscle cell diameters. The mean diameter of muscle cells tended to increase only slightly with increasing fish weight, while the mean density of muscle cells tended to decrease. Using an optimum temperature of $12^{\circ} \mathrm{C}$, an indication of a possible increased rate of hyperplasia in relation to higher growth was seen.
\end{abstract}

Keywords Growth rates · Feed conversion efficiency $\cdot$ Muscle cell dynamics · Temperature $\cdot$ Atlantic halibut

S. V. Larsen and A. K. Imsland have contributed equally.

S. V. Larsen · A. K. Imsland · P. Lohne · K. Pittman

Department of Biology, High Technology Centre, University of Bergen, 5020 Bergen, Norway

A. K. Imsland ( $₫)$

Akvaplan-niva Iceland Office, Akralind 4, 201 Kópavogur, Iceland

e-mail: albert.imsland@akvaplan.niva.no

A. Foss

Akvaplan-niva Bergen, Thormøhlens gate 53D, 5006 Bergen, Norway 


\section{Introduction}

For Atlantic halibut Hippoglossus hippoglossus L., a shift in optimal temperature for growth $\left(\mathrm{T}_{\mathrm{opt}} \mathrm{G}\right)$ with size has been found in several studies (Hallaråker et al. 1995; Björnsson and Tryggvadóttir 1996; Aune et al. 1997; Jonassen et al. 1999). The $\mathrm{T}_{\mathrm{opt}} \mathrm{G}$ for four size classes of juvenile halibut were found to be $14.9^{\circ} \mathrm{C}(5-10 \mathrm{~g}), 13.9^{\circ} \mathrm{C}$ $(20-25 \mathrm{~g}), 13.0^{\circ} \mathrm{C}(40-50 \mathrm{~g})$ and $12.7^{\circ} \mathrm{C}(60-70 \mathrm{~g})$ by Jonassen et al. (1999). Similar results were obtained by Björnsson and Tryggvadóttir (1996) but in a wider size range, where $\mathrm{T}_{\text {opt }} \mathrm{G}$ for $8-60 \mathrm{~g}$ was estimated to $14.2^{\circ} \mathrm{C}$. The optimal temperature for feed conversion efficiency $\left(\mathrm{T}_{\mathrm{opt}} \mathrm{FCE}\right.$ ) is generally found to be lower than $\mathrm{T}_{\mathrm{opt}} \mathrm{G}$ (Jobling 1994), and for halibut this is more pronounced in larger $(0.1-5 \mathrm{~kg})$ than in juvenile individuals (Björnsson and Tryggvadóttir 1996; Jonassen et al. 1999). The findings of different temperature optimas for different size classes together with the downward trend of the $\mathrm{T}_{\text {opt }} \mathrm{G}$ and $\mathrm{T}_{\mathrm{opt}} \mathrm{FCE}$ with size can be summarized in what is called the "stepwisetemperature-hypothesis" (Imsland et al. 2007a). Instead of using constant rearing temperatures, one utilizes specific "temperature-steps", whereby the fish are reared at optimum temperatures defined for each size class. The possible benefits of "temperaturesteps" were verified experimentally in Atlantic halibut by Aune et al. (1997). In their study, Atlantic halibut (140-383 g) were reared at two constant temperatures (11 and $\left.14^{\circ} \mathrm{C}\right)$, and fish were transferred from either 11 to $14^{\circ} \mathrm{C}(\mathrm{F} 11: 14)$ or from 14 to $11^{\circ} \mathrm{C}$ (F14:11). After 3 months, mean weights were significantly higher in the group in which the downward "temperature-step" was used (i.e. F14:11, final mean weight $384 \mathrm{~g}$ ) compared to the group that was reared at constant temperature (constant $14^{\circ} \mathrm{C}$, final mean weight $317 \mathrm{~g}$ ). In other words, an $18 \%$ mean weight gain in only 3 months was demonstrated. Recently, two long-term experiments have been conducted on Atlantic cod, Gadus morhua L., (Imsland et al. 2007b) and on turbot, Scophthalmus maximus Rafinesque (Imsland et al. 2008), and both trials indicated that a short-term temperature manipulation during juvenile stages may have long-term effects on biomass outcome at later stages.

Fish muscle growth can be characterized by its high plasticity and may be altered by a wide range of environmental and endogenous signals (Johnston 1999, 2006). Temperature may influence the muscle growth patterns by a modulation of the rates of hypertrophy and hyperplasia of muscle fibres (Johnston et al. 2003a; Albors et al. 2008). The effect of manipulation of light and temperature on muscle growth patterns in adult halibut (initial mean weight $1.6 \mathrm{~kg}$ ) was evaluated by Haugen et al. (2006). They found that muscle growth patterns were significantly affected by season and that recruitment of fibres seemed to occur mainly during the winter (Haugen et al. 2006). However, little is known about growth of the myotomal muscle in juvenile halibut. Stereology is a set of simple and efficient methods for the quantization of three-dimensional microscopic structures which is specifically tuned to provide reliable data from sections (Gundersen et al. 1988a). In this study, it was applied for a quantitative analysis of the muscle cells derived from histological sections.

In the present experiment, the effect of constant and stepwise temperature regimes on growth, feed conversion efficiency and muscle growth pattern in Atlantic halibut was investigated. The primary objective was to identify the optimum temperature regimes with respect to growth efficiency at individual and cellular level in Atlantic halibut. An effort was made to see whether possible differences in growth observed between groups could be related to muscle growth patterns at an individual level. 


\section{Materials and methods}

\section{Pre-experimental protocol}

The juvenile Atlantic halibut used for this study were produced from a pooled egg-batch at AGA Marin's production facilities at Bømlo, Norway. From the time of first feeding (midFebruary), the larvae were reared at a continuous light regime and an average temperature at around $11.5^{\circ} \mathrm{C}$. On 18 September 2007, the $\sim 3$-g juveniles were transported from AGA Marin to the Industrial Laboratory (ILAB) at the Bergen High Technology Centre Ltd. (BHTC) where they were evenly distributed into five $1-\mathrm{m}^{2}$ square grey fibreglass tanks with a rearing volume of 4001 . All tanks were supplied with a salinity of $34.5 \pm 0.2 \mathrm{ppt}$. The water flow was initially set to $61 \mathrm{~min}^{-1}$ but later (January) increased to $81 \mathrm{~min}^{-1}$. Oxygen was measured daily in the effluent water of all tanks and kept above $80 \%$ at all times. Before the beginning of the experiment, all groups were reared at $10^{\circ} \mathrm{C}( \pm 0.2)$ and at a simulated natural light regime $(\mathrm{N})$, including twilight periods, of Bergen town $\left(60^{\circ} 25^{\prime} \mathrm{N}\right.$ and $\left.5^{\circ} 20^{\prime} \mathrm{E}\right)$ that was maintained by the use of a $30-\mathrm{W}$ fluorescent daylight tube integrated in the tank-cover. Photoirradiance at the tank bottom was approximately $1.38 \mu \mathrm{mol} \mathrm{m} \mathrm{m}^{-2} \mathrm{~s}^{-1}$.

The halibut were fed a commercial formulated feed (3-mm pellet size, Europa marin S3, Skretting A/S, Norway), containing $51 \%$ protein, $21 \%$ fat, $9 \%$ crude carbohydrate, which was provided in excess twice a day $(0800-1,000$ and $1,400-1,600)$ by automatic feeders. Excess feed was collected in the effluent water in a sieve and then weighed after each feeding to calculate ingested feed. No feed was provided $24 \mathrm{~h}$ prior to sampling, or at sampling day.

\section{Experimental design}

On 26 November, 217 juvenile halibut were tagged intraperitoneally with Trovan ${ }^{\circledR}$ Passive transponder tags (PIT tags). The fish were randomly selected from the five tanks and anesthetized ( $0.05 \mathrm{~g} \mathrm{l}^{-1}$ metacain, final concentration) before tagging.

On 30 November, a total of 804 tagged and untagged juvenile halibut were evenly and randomly distributed into $8\left(1 \mathrm{~m}^{2}\right)$ tanks, with approximately 27 tagged and 74 untagged juveniles in each tank. Mean initial weight $( \pm$ SEM) was $14.2 \mathrm{~g}( \pm 0.2)$ and did not differ between treatment groups (two-way nested ANOVA, $P>0.28$ ). There were four rearing regimes with two replicates in each experimental regime: constant (C) 9,12 , and $15^{\circ} \mathrm{C}$ in addition to a temperature-step (T-step) group. The term temperature-step refers to a group that was stepwise adjusted down from 15 to $12^{\circ} \mathrm{C}$ on 8 January (after 36 days) over a 2-day period. The groups are hereafter denoted as: C9, C12, C15 and T-step. Temperature was measured daily in each tank by using a portable OxyGuard (precision of $0.1^{\circ} \mathrm{C}$, Blokken, Denmark) and remained within $0.2^{\circ} \mathrm{C}$ of the thermic value prescribed for each experimental group. The trial lasted from 3 December 2007 to 11 March 2008.

Growth and feed conversion efficiency

Weighing was conducted approximately at 30-35 days intervals until 11 March 2008. Specific growth rate (SGR) was calculated according to the formula of Houde and Schekter (1981):

$$
\mathrm{SGR}=\left(e^{g}-1\right) 100
$$


where $g=\left(\ln \left(W_{2}\right)-\ln \left(W_{1}\right)\right)\left(t_{2}-t_{1}\right)$ and $W_{2}$ and $W_{1}$ are weights measured on days $t_{2}$ and $t_{1}$, respectively.

Geometric mean (GM) weights were calculated using the formula:

$$
\mathrm{GM}=\left(W_{1} * W_{2}\right)^{1 / 2}
$$

where $W_{1}$ and $W_{2}$ are individual weights for tagged fish in each replicate at $t_{1}$ and $t_{2}$. GM values were used in SGR-GM regressions for all treatment groups.

Total feed consumption $\left(C_{\mathrm{T}}\right)$ was calculated as total feed supplied-total remaining feed. $C_{\mathrm{T}}$ was calculated on a daily basis and then summarized for each tank. Daily feeding rate $(F \%)$ was calculated as

$$
\left.F \%=100\left[C /\left(B_{1}+B_{2}\right) / 2\right)\right]\left(t_{2}-t_{1}\right)^{-1}
$$

where $C$ is feed consumption $(g)$ in the period, and $B_{1}$ and $B_{2}$ are fish biomass $(g)$ on days $t_{1}$ (start) and $t_{2}$ (final), respectively. Feed conversion efficiency (FCE) was calculated as biomass gain per unit weight of feed consumed:

$$
\mathrm{FCE}=\left(B_{2}-B_{1}\right) / C
$$

Histology and stereological analysis

Muscle samples were collected from two untagged fish in each experimental group on 6 February (day 36) and 10 March (day 98). Each fish was killed by a quick blow to the head before it was weighed, and a sample of the muscle was extracted for further stereological analysis. A thin $(\sim 2 \mathrm{~mm})$ steak crosscut dorsal to the posterior wall of the abdomen was transferred immediately after collection to individually marked plastic tubes where it was fixed in buffered formaldehyde (4\%) for $>24 \mathrm{~h}$, washed approximately $30 \mathrm{~s}$ in Sørensens buffer (14 ml of $0.2 \mathrm{M}, \mathrm{NaH}_{2} \mathrm{PO}_{4}$ mixed with $36 \mathrm{ml}$ of $0.2 \mathrm{M}, \mathrm{Na}_{2} \mathrm{HPO}_{4}, \mathrm{pH} 7.2$ ) three times and then stored at room temperature in closed plastic tubes containing $70 \%$ ethanol. The epaxial quadrant of mediolateral muscle was selected, and no correction was made for the possible development of internal red fibre bands within the white muscle tissue. Later, the sections were dehydrated in 80 and $96 \%$ ethanol for $1 \mathrm{~h}$ each followed by embedding in Technovit 7100 resin system (Heraeus Kulzer, Germany). Transverse histological sections $(3 \mu \mathrm{m})$ were cut by using a microtome (Leica RM 2255, Germany) stretched in a heated water bath $\left(40^{\circ} \mathrm{C}\right)$, transferred to a glass slide and dried on a heated plate $\left(50^{\circ} \mathrm{C}\right)$.

The stereological analyses were done using Visiopharm NewCAST software (Version 3.0.13.0, Hørsholm, Denmark) calibrated with a microscope (Axioskop, Carl Zeiss, Oberkochen, Germany), a digital camera (Olympus DP 72) and 2.5× and 20× objectives. A random selection of right or left compartment from day 36 was used for stereological analysis, whereas on day 98 the side presenting the best quality was selected. The same compartment of two non-sequential transverse sections from each fish was analysed. The transverse sections were placed under the microscope, the program NewCAST was opened and a digital outline (mask) of the chosen compartment to be further analysed was made manually at $2.5 \times$ magnification. No adjustment was made for lacunae within the masked area, i.e. cracks and tears were nonetheless included as part of the sample area. The total masked area (TMA) was then calculated by the software. The function meander sampling generated a variable number of systematically random distributed counting frames $\left(24,000 \mu \mathrm{m}^{2}\right)$ which assured equal sampling probabilities of $20 \%$ of TMA. Edge effects were avoided by using $2 \mathrm{D}$ sampling frames with inclusion and exclusion lines; the program 
excludes the probability of a cell being counted twice (Gundersen et al. 1988a). Cells without clear borders (surrounding membrane) were not sampled.

The density of cells $\left(n \mathrm{~mm}^{-2}\right)$ in each sample was calculated by the formula:

$$
D=[(n / 20 \%) \times 100 \%] / \text { TMA }
$$

where $D=$ density of cells, $n=$ number of cells counted in the sample and TMA $=$ total masked area $\left(\mathrm{mm}^{2}\right)$ of the sample.

The area $\left(\mu \mathrm{m}^{2}\right)$ of each counted cell was estimated by the function "nucleator" giving an unbiased estimation of cell area, where the distance is measured from a fixed point in the cell to the borders of the cell in a random (isotropic) direction (Gundersen et al. 1988b). These estimated areas were used to calculate cell diameter $(\mu \mathrm{m})$ by the following formula:

$$
\Phi=[A /(\pi / 4)]^{1 / 2}
$$

where $\Phi$ is the calculated diameter $(\mu \mathrm{m})$ and $A$ is the estimated area of the cell. This is an indirect estimation of $\Phi$ and is defined as the diameter of a circle having the same area as that of a muscle fibre in a perfect cross section. This size descriptor parameter has often been adopted in fish muscle studies (see for instance Valente et al. 1999).

Statistical methods

All statistical analyses were conducted using Statistica ${ }^{\mathrm{TM}}$ 8.0. Mortality between the four experimental groups was tested using a chi-square test (Zar 1984). A KolmogorovSmirnov test (Zar 1984) was used to assess for normality of distributions. The homogeneity of variances was tested using the Levene $F$ test (Zar 1984). The mean weights of the experimental groups on different dates were tested with a two-way nested model III analysis of variance (ANOVA). Two-way analysis of covariance (ANCOVA) was applied to test for possible differences in muscle parameters with fish weight included as a continuous predictor and temperature regime variable. Significant differences revealed in ANOVAs and ANCOVAs were followed by a Student-Newman-Keuls multiple comparison post hoc test to determine differences among experimental groups.

The SGR versus GM regressions were analysed using a two-way covariance analysis (ANCOVA). The model equation of the ANCOVA had the form (Scheffé 1959):

$$
X_{\mathrm{ij}}=\mu+\alpha_{\mathrm{i}}+\gamma\left(z_{\mathrm{ij}}-\bar{z}\right)+\varepsilon_{\mathrm{ij}}
$$

where $\mu$ is the overall mean, $\alpha_{\mathrm{i}}$ is the treatment effect of the temperature groups, $\gamma$ is the regression coefficient for the SGR-GM regression, $z_{\mathrm{ij}}$ is the GM of the fish (covariable), $\bar{z}$ is the mean GM of fish in each temperature group and $\varepsilon_{\mathrm{ij}}$ is the error term.

A significance level $(\alpha)$ of 0.05 was used if not stated otherwise.

\section{Results}

Mortality

Mortality during the experiment was low (1-3\%), and no significant differences in mortality between treatment groups was found $\left(\chi^{2}<3.0, P>0.10\right)$. However, a significant size-dependent mortality was found (one-way ANOVA, $P<0.001$ ), with a larger proportion of small fish found amongst the dead fish. 
Growth

From day 35 and onwards, the C9 group displayed a significantly lower mean weight compared to all other groups (Student-Newman-Keuls test, $P<0.05$, Fig. 1). No significant differences were found in weights between the $\mathrm{C} 12, \mathrm{C} 15$ and the T-step groups at any time.

Mean specific growth rates for the whole experimental period ranged from 0.92 to $2.03 \%$ day $^{-1}$ (Fig. 2). Significant differences in specific growth rates were found between treatments in all periods (Student-Newman-Keuls test, $P<0.05$, Fig. 2). Growth rates were lower in the $\mathrm{C} 9$ group throughout the experimental period. In the third period (days 67-99), the C12 group displayed a significantly higher growth rate at $1.34 \% \mathrm{day}^{-1}$ compared to the C15 and T-step (1.15 and $1.07 \%$ day $^{-1}$, Student-Newman-Keuls test, $P<0.05$, Fig. 2). Overall SGR was significantly lowest in the C9 group (1.17\% day $\left.{ }^{-1}\right)$ and highest in the $\mathrm{C} 12$ group $\left(1.66 \%\right.$ day $\left.^{-1}\right)$ with the $\mathrm{C} 15$ and T-step groups in between (1.56 and $1.54 \%$ day $^{-1}$, Student-Newman-Keuls test, $P<0.05$, Fig. 2). Growth rate decreased with increasing size for $\mathrm{C} 15, \mathrm{C} 12$ and T-step (linear regression, $P<0.05$ ) but was not significant for $\mathrm{C} 9(P>0.14)$. The regression lines of the four experimental groups were non-parallel (two-way ANCOVA, $P<0.001$ ).

Feed consumption, feeding rate and feed conversion efficiency

Mean feed consumption $\left(\mathrm{C}_{\mathrm{T}}\right)$ ranged from 830 to $1,370 \mathrm{~g}$ and was significantly lower in the C9 group compared to the $\mathrm{C} 12, \mathrm{C} 15$ and T-step groups in all three periods and as well as overall (Student-Newman-Keuls test, $P>0.05$, Fig. 3a), whereas only minor differences were found between the other groups (days $0-35$ ). Mean daily feeding rate $(F \%)$ ranged from 0.80 to 1.37 throughout the experiment (Fig. 3b) and the C9 group displayed a significantly lower F\% compared to the $\mathrm{C} 12, \mathrm{C} 15$ and T-step groups in all three periods (Student-Newman-Keuls test, $P>0.05$, Fig. 3b). However, no significance was found between any treatment groups in the overall comparison $(P>0.18)$. Mean feed conversion

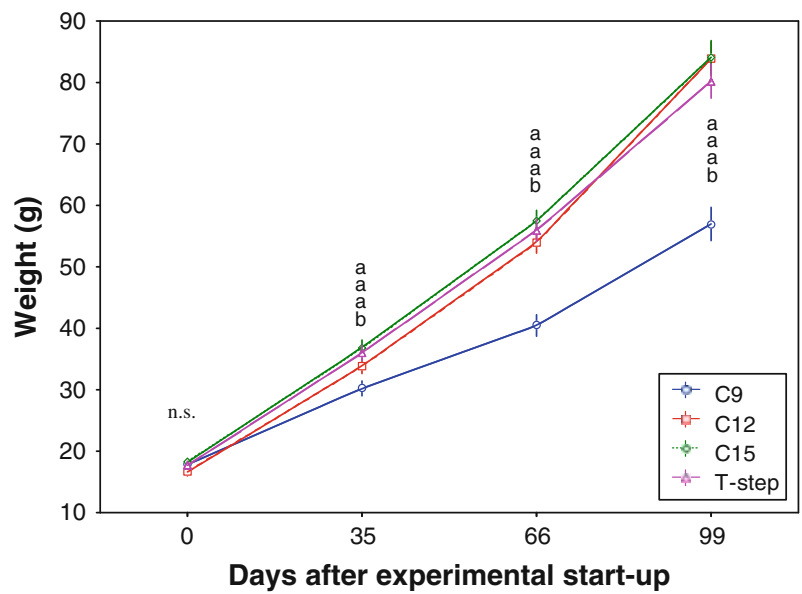

Fig. 1 Mean weight of juvenile Atlantic halibut reared at four different temperature regimes [constant (C) 9,12 and $15^{\circ} \mathrm{C}$, and temperature-step (T-step)]. Vertical whiskers indicate standard error of mean (SEM), $N=52-56$ in each experimental group. Different letters ( $a$ largest group, $b$ second largest) indicate significant statistical difference between treatments (Student-Newman-Keuls test, $P<0.05$ ) at each sampling date, n.s not significant. The T-step temperature was adjusted from 15 to $12^{\circ} \mathrm{C}$ from day 36 


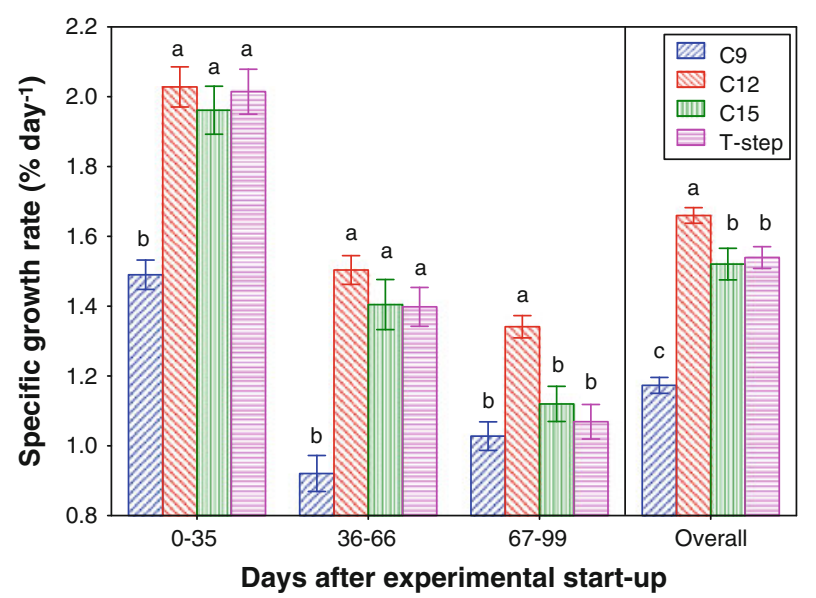

Fig. 2 Growth rates of juvenile Atlantic halibut reared at four different temperature regimes. Vertical whiskers indicate standard error of mean (SEM), $N=52-56$ in each experimental group. Different letters indicate significant statistical difference (Student-Newman-Keuls test, $P<0.05$ ) between treatments within each sampling period

efficiency (FCE) ranged from 1.10 to 1.53 during the experimental period (Fig. 3c). No significant differences were found between treatment groups in the first and the third period and in the overall comparison. In the second period (days 36-66), the C9 group displayed a significantly lower FCE compared to C12, C15 and T-step groups (Student-NewmanKeuls test, $P>0.05$, Fig. 3c).

Muscle growth dynamics

The sampled total masked area (TMA) and the number of cells $(N)$ showed similar trends as both TMA and $N$ differed between $\mathrm{C} 12$ and T-step at day 36 and between all groups at day 98 (Student-Newman-Keuls test, $P<0.001$, Table 1). The average cell diameter $(\Phi)$ varied from $39.02(\mathrm{C} 12)$ to $45.41(\mathrm{C} 15) \mu \mathrm{m}$ at day 36, and from 43.34 (C9) to 46.85 (C12) $\mu \mathrm{m}$ at day 98, but no significant differences were found between treatments (two-way ANCOVA, $P>0.31)$. The diameter muscle fibres of all observations increased slightly with increasing fish weight at day $36(r=0.11)$. Average density $(D)$ of fibres was highest in the C12 group at day 36 and in the C9 group at day 98 (Student-Newman-Keuls test, $P<0.01$, Table 1). A negative relationship was found when all estimated densities of muscle fibres were compared against weight at day $36(r=-0.85)$ and day $98(r=-0.32)$.

The overall size distributions of muscle cell diameter were similar between all treatments (Fig. 4), with the majority of the sampled cells in the smallest size classes (0-40), followed by the middle (40-80) and the biggest (80-120) $\mu \mathrm{m}$ size classes. The size distribution of T-step at day 36 and C15 at day 98 skewed towards larger cells, whereas the size distribution was slightly skewed towards smaller cells in C12 at day 36.

\section{Discussion}

The T-step rearing did not lead to improved growth in the present study as the overall growth was lowest in the $\mathrm{C} 9$ group $\left(1.17 \% \mathrm{day}^{-1}\right)$, highest in the $\mathrm{C} 12$ group $\left(1.66 \% \mathrm{day}^{-1}\right)$ 

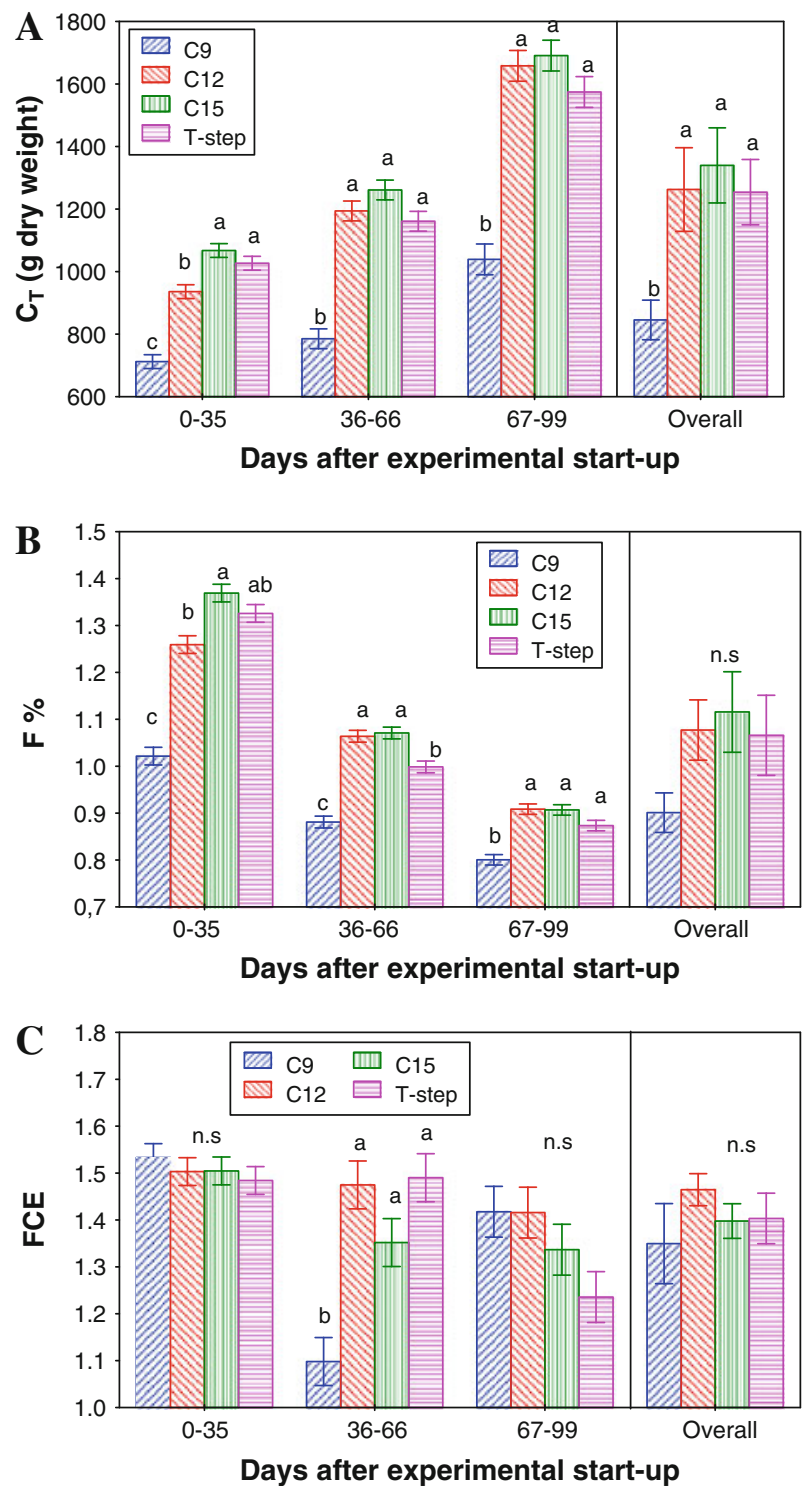

Fig. 3 Total feed consumption (a), daily feeding rate (b) and feed conversion efficiency (c) of juvenile Atlantic halibut reared at four different temperature regimes. Vertical whiskers indicate standard error of mean (SEM). Different letters indicate significant statistical difference (Student-Newman-Keuls test, $P<0.05)$ between treatments within each sampling period. n.s not significant

with the $\mathrm{C} 15$ and $\mathrm{T}$-step groups in between (1.56 and $1.54 \%$ day $^{-1}$ ). The reported optimum temperatures for growth $\left(\mathrm{T}_{\mathrm{opt}} \mathrm{G}\right)$ in juvenile Atlantic halibut (Table 2) suggest that the optimum temperature for growth in juvenile halibut in the size range between $5-70 \mathrm{~g}$ is between 12 and $15^{\circ} \mathrm{C}$ and it decreases with size (Jonassen et al. 1999; Hallaråker et al. 1995; Björnsson and Tryggvadóttir 1996). Uncoupled (Jonassen et al. 1999; Imsland et al. 2005, 2006; the C9 group in the present study) and increased (Hallaråker et al. 1995; 
Table 1 Total masked area (TMA, $\left.\mathrm{mm}^{2}\right)$, average diameter of muscle fibres $(\Phi, \mu \mathrm{m})$, average number of counted muscle fibres $(n)$ and density of muscle fibres $\left(\nexists, n \mathrm{~mm}^{-2}\right)$ in juvenile Atlantic halibut reared at three constant temperatures $\left(9,12\right.$ and $\left.15^{\circ} \mathrm{C}\right)$ and temperature-step (T-step) regime

\begin{tabular}{lcccc}
\hline & C9 & \multicolumn{1}{c}{ C12 } & C15 & T-step \\
\hline Day 36 & & & & \\
TMA & $17.65 \pm 1.45^{\mathrm{ab}}$ & $18.08 \pm 0.56^{\mathrm{a}}$ & $17.57 \pm 1.46^{\mathrm{ab}}$ & $16.02 \pm 0.49^{\mathrm{b}}$ \\
$\Phi$ & $44.62 \pm 6.84$ & $39.02 \pm 9.32$ & $45.41 \pm 1.74$ & $45.16 \pm 9.68$ \\
$n$ & $171.12 \pm 10.26^{\mathrm{b}}$ & $284.44 \pm 23.21^{\mathrm{a}}$ & $173.68 \pm 7.98^{\mathrm{b}}$ & $165.87 \pm 10.10^{\mathrm{b}}$ \\
$Ð$ & $49.02 \pm 3.13^{\mathrm{b}}$ & $68.87 \pm 6.37^{\mathrm{a}}$ & $50.55 \pm 4.31^{\mathrm{b}}$ & $51.77 \pm 2.65^{\mathrm{b}}$ \\
Day 98 & & & & \\
TMA & $17.53 \pm 1.98^{\mathrm{c}}$ & $12.31 \pm 0.21^{\mathrm{d}}$ & $28.03 \pm 2.11^{\mathrm{a}}$ & $23.49 \pm 0.68^{\mathrm{b}}$ \\
$\Phi$ & $43.34 \pm 6.33$ & $46.85 \pm 18.47$ & $44.87 \pm 19.76$ & $44.42 \pm 14.82$ \\
$n$ & $186.31 \pm 12.84^{\mathrm{c}}$ & $107.09 \pm 3.28^{\mathrm{d}}$ & $276.68 \pm 18.98^{\mathrm{a}}$ & $221.24 \pm 7.42^{\mathrm{b}}$ \\
$Ð$ & $54.33 \pm 4.28^{\mathrm{a}}$ & $43.51 \pm 1.31^{\mathrm{b}}$ & $49.54 \pm 1.07^{\mathrm{ab}}$ & $47.18 \pm 1.80^{\mathrm{b}}$ \\
\hline
\end{tabular}

The values are given as means \pm SE estimated from 2 fish per treatment and 2 slides per fish $(n=4)$. Different letters indicate significant statistical differences (Student-Newman-Keuls test, $P<0.05$ ) between treatments in each sampling period

Imsland et al. 1996) growth rates with increasing size in studies where fish have been reared at suboptimal temperatures has been suggested to indicate an ontogenetic shift in the optimal temperature for growth (Imsland et al. 1996). But, for a successful outcome, the T-step rearing temperature must be reduced in accordance with the estimated $\mathrm{T}_{\text {opt }} \mathrm{G}$ for the specific size interval, i.e. mimicking the ontogenetic shift. In this study, the T-step group was moved from 15 to $12^{\circ} \mathrm{C}$ after 36 days when the mean weight was $35.4 \mathrm{~g}$. This might have been too late compared to the estimated $\mathrm{T}_{\text {opt }} \mathrm{G}$ by Jonassen et al. (1999). Consequently, the fish in the T-step group had already grown out of $15^{\circ} \mathrm{C}$ as its optimum temperature for growth during the first period of the experiment. In contrast to this study, Aune et al. (1997) observed higher end weights and overall growth rates for juvenile halibut in a T-step $\left(14-11^{\circ} \mathrm{C}\right)$ group and a $\mathrm{C} 11$ when compared to groups at $\mathrm{C} 14$ and $11-14^{\circ} \mathrm{C}$. A possible explanation for the discrepancy between Aune et al. (op. cit.) and the present study is the size range investigated. Although it is suggested that the $\mathrm{T}_{\mathrm{opt}} \mathrm{G}$ drops most rapidly between 5 and $50 \mathrm{~g}$ for halibut and turbot (Imsland et al. 1996; Jonassen et al. 1999), $14^{\circ} \mathrm{C}$ is presumably more suboptimal for halibut in the size range $>100 \mathrm{~g}$ than for halibut in the size range $<100 \mathrm{~g}$.

Total feed consumption and daily feeding rate was temperature dependent (lower at $9^{\circ} \mathrm{C}$ ) in the present study. This is in line with the general trend that the ingestion rate will increase towards an optimum with increasing temperature (Jobling 1994). Only minor differences in feed conversion efficiency (FCE) between temperature groups in this study were found in accordance with previous studies on Atlantic halibut (Björnsson and Tryggvadóttir 1996; Jonassen et al. 2000). Most groups displayed increasing consumption, and slightly decreasing feeding rate and FCE over time, but the C9 displayed an aberrant and significantly lower FCE between days 36-66. Jonassen et al. (op. cit.) did not find significant differences in FCE between temperature groups reared at 12 and $6^{\circ} \mathrm{C}$ for juvenile halibut in the size range of 10-70 g. Björnsson and Tryggvadóttir (1996) described the relationship between FCE and temperature as relatively flat around the optimal temperatures, and generally $\mathrm{T}_{\text {opt }} \mathrm{FCE}$ is lower than $\mathrm{T}_{\text {opt }} \mathrm{G}$ (Jonassen et al. 1999). Accordingly, the increased growth observed for the groups at a higher temperature in this study was most 
Fig. 4 Distribution ( $N$ number of muscle cells) of cell diameter $(\mu \mathrm{m})$ in juvenile Atlantic halibut reared at four temperature regimes after 36 (a) and 98 (b) days from start of the experiment. Numbers above bars show frequency of cells (\% of total in each temperature regime) in eight size intervals
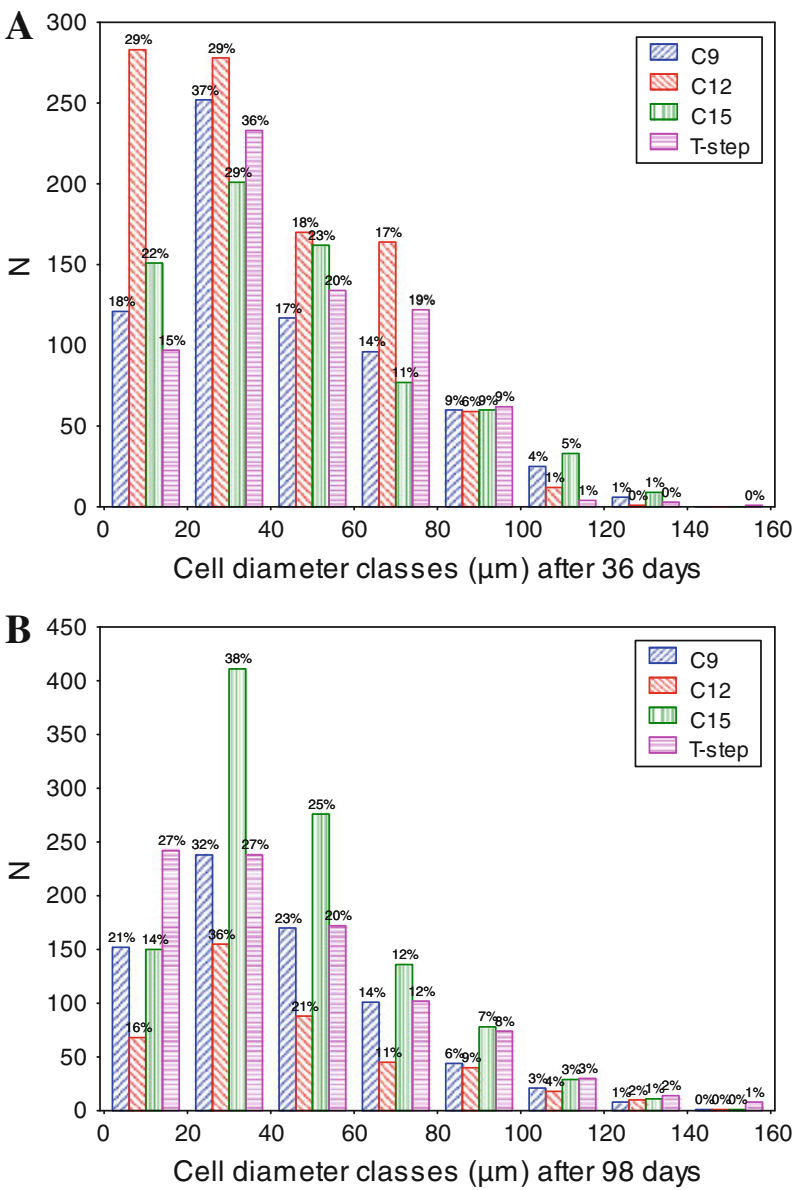

likely the result of an increased food intake (indicated by increased $C_{\mathrm{T}}$ and $F \%$ ), rather than an increased FCE.

Most previous studies where the effect of temperature of post-embryonic muscle growth was investigated involve a modulation of the temperature already during the two first phases of myogenesis: embryonic and stratified hyperplasia (Johnston et al. 2000, 2003a; Johnston 2006). It has been suggested that early temperature may affect the number, proliferative capacity or cell cycle time of the myogenic progenitor cells (MPC) and further modulate the relative importance of fibre recruitment and hypertrophy to muscle growth at later stages of the life cycle (Johnston et al. 2000, 2003a). Hyperplastic growth is commonly associated with rapid growth in fish, whereas hypertrophic growth is associated with slow growth (Rowlerson and Veggetti 2001; Johnston 2006). Studies evaluating the muscle dynamics from manipulations of the temperature or other environmental factors solely in the juvenile period are limited. Normally if size is taken into account, alterations in growth rate during the juvenile period generally have parallel effects on the rates of hypertrophy and hyperplasia, especially in fish which grow to a large size and which may use mosaic hyperplasia (Rowlerson and Veggetti 2001) and making a contribution to the market size of fishes (Kiessling et al. 2006). Throughout our study, we found more than half of all 
Table 2 An overview of previous temperature studies on juvenile Atlantic halibut and studies evaluating the effect of T-step group (below stippled line)

\begin{tabular}{|c|c|c|c|c|c|c|}
\hline $\begin{array}{l}\text { Size } \\
\text { range } \\
(g)\end{array}$ & Temp. & Photoperiod & T-step & $\mathrm{T}_{\mathrm{opt}} \mathrm{G}$ & Growth results & Source \\
\hline $5-10$ & $\begin{array}{r}6,9,11 \\
13,16\end{array}$ & LD 20:4 & & 14.9 & & $\begin{array}{l}\text { Jonassen et al. } \\
\text { (1999) }\end{array}$ \\
\hline $8-60$ & $\begin{array}{l}7.3,10.0 \\
12.8,15.0\end{array}$ & $\begin{array}{l}\text { LDN and } \\
\text { LD } 12: 12\end{array}$ & & 14.2 & $\begin{array}{l}\text { End weight } 35 \% \text { lower } \\
\text { at } 10^{\circ} \mathrm{C} \text { versus } 12.8^{\circ} \mathrm{C}\end{array}$ & $\begin{array}{l}\text { Björnsson and } \\
\text { Tryggvadóttir } \\
\text { (1996) }\end{array}$ \\
\hline $20-25$ & $6,9,11,13,16$ & LD 20:4 & & 13.9 & & $\begin{array}{l}\text { Jonassen et al. } \\
\text { (1999) }\end{array}$ \\
\hline $40-50$ & $6,9,11,13,16$ & LD 20:4 & & 13.0 & & $\begin{array}{l}\text { Jonassen et al. } \\
\text { (1999) }\end{array}$ \\
\hline $60-70$ & $6,9,11,13,16$ & LD 20:4 & & 12.7 & $\begin{array}{c}\text { Highest SGR }\left(1.62 \% \text { day }^{-1}\right) \\
\text { and final weight at } 13{ }^{\circ} \mathrm{C}\end{array}$ & $\begin{array}{l}\text { Jonassen et al. } \\
\text { (1999) }\end{array}$ \\
\hline $20-90$ & $7,10,13,16$ & $\mathrm{LDN}$ & & 12.7 & $\begin{array}{l}\text { Best overall SGR } 10-13^{\circ} \mathrm{C} \text { : } \\
1.7-2.0 \% \mathrm{day}^{-1}\end{array}$ & $\begin{array}{l}\text { Hallaråker et al. } \\
\text { (1995) }\end{array}$ \\
\hline $18-76$ & $9,12,15$ & $\mathrm{LDN}$ & $15-12$ & & $\begin{array}{l}\text { Highest equal end weights } 12 \text {, } \\
15 \text { and T-step. Best overall } \\
\text { SGR at } 12^{\circ} \mathrm{C}: 1.66 \% \text { day }^{-1}\end{array}$ & This study \\
\hline $140-383$ & 11,14 & LDN & $14-11$ & & $\begin{array}{l}\text { Highest end weights for } \\
\text { T-step and } 11^{\circ} \mathrm{C} \text {. }\end{array}$ & $\begin{array}{l}\text { Aune et al. } \\
\text { (1997) }\end{array}$ \\
\hline
\end{tabular}

Size range $(\mathrm{g})$, temperature $\left({ }^{\circ} \mathrm{C}\right)$, photoperiod (light day natural $=\mathrm{LDN}$, light dark $\left.=\mathrm{LD}\right)$, calculated optimal temperature for growth $\left(\mathrm{T}_{\mathrm{opt}} \mathrm{G},{ }^{\circ} \mathrm{C}\right)$, and summarized growth results are shown

fibres in each temperature regime were $<40 \mu \mathrm{m}$ in diameter, supporting Rowlerson and Veggetti 2001 that zonal differences are low in large fish. The highest number of small fibres $(<20 \mu \mathrm{m})$ was found in the $\mathrm{C} 12$ group after 36 days, suggesting a relatively prolonged period of hyperplasia in this group. The number of small fibres decreased dramatically in this group after 98 days, agreeing with Valente et al. (1999) who found that the decrease in small-sized cells started sooner in fast-growing rather than slow-growing rainbow trout. Furthermore, in the $\mathrm{C} 12$ group of halibut, the distribution of cell size classes was more extended and even at day 98 , indicating the starting of a period dominated by hypertrophy.

By contrast, the T-step group exhibited its highest percentage of small fibres after day 98, indicating a positive effect of temperature drop on rates of hyperplasia, and where effects on growth may appear subsequently. Thus, mosaic hyperplasia, usually most intense during early juvenile life, seems to have been stimulated by the T-step regime and may ultimately contribute to the attainment of market size (Kiessling et al. 2006). Albors et al. (2008) observed increased rates of hyperplasia in juvenile sea bass (initial equal muscle cellularity, size range 50-200 g) after experiencing elevated temperatures during the winter/spring period. Interestingly, these groups showed a reduced capacity to recruit fibres in the following summer, when growth in seabass is more pronounced. The authors speculated that the MPC cells first fused to create new myotubes (hyperplasic effect) but that they in the following summer were absorbed by mature muscle fibres (hypertrophic effect). This may indicate that the mechanisms responding to a temperature modulation are not unidirectional, but may alter both hyperplasia and hypertrophia through the behaviour of the MPC, the regulation of which has not been fully investigated yet (Johnston 2006). 
Our study shows differences in muscle fibre size distribution patterns within each temperature regime over time and supports the possibility of steering growth capacity through careful manipulation of temperature in the juvenile stage.

In this study, the average diameter changed little with increasing fish weight (only slightly positive), while the density decreased with increasing fish size, resulting in a negative overall correlation $(r=-0.81)$ between the diameter and the density of cells. Decreased density of fibres with increasing size has also been found for Atlantic salmon, while the estimated total fibre number simultaneously increased (Johnston et al. 2003b). The intuitive explanation for this is that as the fish grow in size, more fibres are recruited, resulting in a higher total number of fibres, while at the same time the fibres increase in diameter at a higher rate than does the recruitment of cells, resulting in a lower density (Johnston et al. 2003b). The temporal correspondence between changes in muscle cellularity and fish growth is a broad avenue for further investigation.

\section{Conclusion}

Despite indications of an ontogenetic shift, only a limited effect of T-step rearing was observed in halibut (stimulation of hyperplasia by the temperature drop) and overall growth rate was highest in the $\mathrm{C} 12$ group. Differences in growth were reflected more by alterations in feed intake $\left(C_{\mathrm{T}}\right.$ and $F \%$ ) than by differences in feed conversion efficiencies (FCE). Indication of a possible prolonged period of hyperplasia followed by a relatively early dominance of hypertrophy and higher growth at optimum temperature (here $12^{\circ} \mathrm{C}$ ) was seen in the present study. The findings support the possibility of steering long-term growth patterns through careful manipulation of temperature regimes in the juvenile stage.

Acknowledgments This study was financed by the Norwegian Research Council (No. 180088/120).

Open Access This article is distributed under the terms of the Creative Commons Attribution Noncommercial License which permits any noncommercial use, distribution, and reproduction in any medium, provided the original author(s) and source are credited.

\section{References}

Albors OL, Abdel I, Periago MJ, Ayala MD, Alcázar AG, Graciá CM, Nathanailides C, Vázquez JM (2008) Temperature influence on the white muscle growth dynamics of the sea bass Dicentrarchus labrax, L. Flesh quality implications at commercial size. Aquaculture 277:39-51

Aune A, Imsland AK, Pittman K (1997) Growth of juvenile halibut, Hippoglossus hippoglossus (L.), under a constant and switched temperature regime. Aqua Res 28:931-939

Björnsson B, Tryggvadóttir SV (1996) Effect of size on optimal temperature for growth and growth efficiency of immature Atlantic halibut (Hippoglossus hippoglossus L.). Aquaculture 142:33-42

Gundersen HJG, Bendtsen TF, Korbo L, Marcussen N, Møller A, Nielsen K, Nyengaard JR, Pakkenberg B, Sørensen FB, Vesterby A, West MJ (1988a) Some new, simple and efficient stereological methods and their use in pathological research and diagnosis. Review. APMIS 96:379-394

Gundersen HJG, Bagger P, Bendtsen TF, Evans SM, Korbo L, Marcussen N, Møller A, Nielsen K, Nyengaard JR, Pakkenberg B, Sørensen FB, Vesterby A, West MJ (1988b) Disector, fractionator, nucleator and point sampled intercepts and their use in pathological research and diagnosis. APMIS 96:857-881

Hallaråker H, Folkvord A, Stefansson SO (1995) Growth of juvenile halibut (Hippoglossus hippoglossus) related to temperature, day length and feeding regime. Neth J Sea Res 34:139-147

Haugen T, Kiessling A, Olsen RE, Rørå MB, Slinde E, Nordvedt R (2006) Seasonal variations in muscle growth dynamics and selected quality attributes in Atlantic halibut (Hippoglossus hippoglossus L.) fed 
dietary lipids containing soybean and/or herring oil under different rearing regimes. Aquaculture 261:565-579

Houde ED, Schekter RC (1981) Growth rates, rations and cohort consumption of marine fish larvae in relation to prey concentrations. Rapp Proc-verb Réun Con inter 1'Explor Mer 178:441-453

Imsland AK, Sunde LM, Folkvord A, Stefansson SO (1996) The interaction of temperature and fish size on growth of juvenile turbot. J Fish Biol 49:926-940

Imsland AK, Foss A, Folkvord A, Stefansson SO, Jonassen TM (2005) The interrelation between temperature regimes and fish size in juvenile Atlantic cod (Gadus morhua): effects on growth and feed conversion efficiency. Fish Physiol Biochem 31:347-361

Imsland AK, Foss A, Sparboe LO, Sigurdsson S (2006) The effect of temperature and fish size on growth and feed efficiency ratio of juvenile spotted wolffish Anarhichas minor. J Fish Biol 68:1107-1122

Imsland AK, Schram E, Roth B, Schelvis-Smit R, Kloet K (2007a) Improving growth in juvenile turbot (Scophthalmus maximus Rafinesque) by rearing fish in switched temperature regimes. Aqua Int 15:403-407

Imsland AK, Foss A, Koedijk R, Folkvord A, Stefansson SO, Jonassen TM (2007b) Persistent growth effects of temperature and photoperiod in Atlantic cod Gadus morhua. J Fish Biol 71:1371-1382

Imsland AK, Gunnarsson S, Ásgeirsson Á, Roth B, Schram E, Foss A (2008) Commercial-scale validation of temperature-step rearing on growth physiology in turbot, Scophthalmus maximus. J World Aqua Soc 39:684-690

Jobling M (1994) Fish bioenergetics. Chapman and Hall, London, p 309

Johnston IA (1999) Muscle development and growth: potential implications for flesh quality in fish. Aquaculture 177:99-115

Johnston IA (2006) Environment and plasticity of myogenesis in teleost fish. J Exp Biol 209:2249-2264

Johnston IA, McLay HA, Abercromby M, Robins D (2000) Early thermal experience has different effects on growth and muscle fibre recruitment in spring- and autumn- running Atlantic salmon populations. J Exp Biol 203:2553-2564

Johnston IA, Manthri S, Alderson R, Smart A, Campbell P, Nickell D, Robertson B, ChGM Paxton, Burt ML (2003a) Freshwater environment affects growth rate and muscle fibre recruitment in seawater stages of Atlantic salmon (Salmo salar L.). J Exp Biol 206:1337-1351

Johnston IA, Manthri S, Smart A, Campell P, Nickell D, Alderson R (2003b) Plasticity of muscle fibre number in seawater stages of Atlantic salmon in response to photoperiod manipulation. J Exp Biol 206:3425-3435

Jonassen TM, Imsland AK, Stefansson SO (1999) The interaction of temperature and fish size on growth of juvenile halibut. J Fish Biol 54:556-572

Jonassen TM, Imsland AK, Kadowaki S, Stefansson SO (2000) Interaction of temperature and photoperiod on growth of Atlantic halibut Hippoglossus hippoglossus L. Aqua Res 31:219-227

Kiessling A, Ruohonen K, Bjørnevik M (2006) Muscle fibre growth and quality in fish. Arch Tierz Dummerstorf 49:137-146

Rowlerson A, Veggetti A (2001) Cellular mechanisms of post-embryonic muscle growth in aquaculture species. In: Johnston IA (ed) Muscle development and growth. Academic press, California, pp 103-140

Scheffé H (1959) The analysis of variance. Wiley, New York, p 477

Valente LMP, Rocha E, Gomes EFS, Silva MW, Oliveira MH, Monteiro RAF, Fauconneau B (1999) Growth dynamics of white and red muscle fibres in fast- and slow-growing strains of rainbow trout. J Fish Biol 55:675-691

Zar JH (1984) Biostatistical analysis. Prentice-Hall, New Jersey, p 718 